WellBeing International

WBI Studies Repository

$12-2007$

\title{
The Long Haul: Risks Associated with Livestock Transport
}

Michael Greger

The Humane Society of the United States

Follow this and additional works at: https://www.wellbeingintlstudiesrepository.org/acwp_faafp

Part of the Agribusiness Commons, Animal Studies Commons, and the Operations and Supply Chain Management Commons

\section{Recommended Citation}

Greger, M. (2007). The long haul: Risks associated with livestock transport. Biosecurity and Bioterrorism: Biodefense Strategy, Practice, and Science, 5(4), 301-312.

This material is brought to you for free and open access by WellBeing International. It has been accepted for inclusion by an authorized administrator of the WBI Studies Repository. For more information, please contact wbisr-info@wellbeingintl.org.

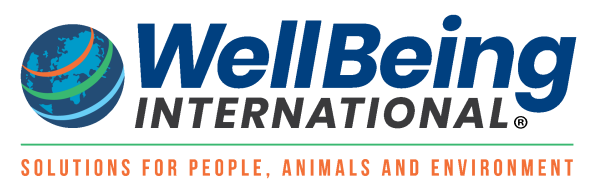




\title{
The Long Haul: Risks Associated WITH LIVESTOCK TRANSPORT
}

\author{
Michael Greger
}

$\mathrm{T}$ He Food and Agriculture Organization (FAO) of the United Nations describes live animal transport as "ideally suited for spreading disease," given that animals may originate from different herds or flocks and are "confined together for long periods in a poorly ventilated stressful environment." Given the associated "serious animal and public health problems," the Federation of Veterinarians of Europe has called for the replacement of the longdistance transportation of live animals for slaughter as much as possible to a "carcass-only trade."

In the United States, more than 50 million live cattle, sheep, and pigs ${ }^{3}$ and an unknown number of the more than 9 billion chickens, turkeys, and other birds raised for food ${ }^{4}$ are annually traded across state lines. Before they are slaughtered, U.S. livestock may travel an average of 1,000 miles. ${ }^{5}$ These factors and activities may have undesirable animal and public health implications.

\section{STRESSORS}

According to the FAO, " $[\mathrm{t}]$ ransport of livestock is undoubtedly the most stressful and injurious stage in the chain of operations between farm and slaughterhouse" and can lead to a significant loss of production. ${ }^{6}$ The immunosuppressive stress of prolonged transport may not only increase a healthy animal's susceptibility to infection, but it may trigger the emergence of a variety of diarrheal and respiratory diseases caused by endogenous microoganisms that might not normally lead to disease. So-called "shipping fever," for example, the bovine version of which costs U.S. producers more than $\$ 500$ million a year, is often caused by latent pathogens that may become active when shipping cattle long distances?
Long-distance transport also may increase the fecal shedding of disease agents. Barham and colleagues found the average prevalence of Salmonella within feces and on the hides of cattle was $18 \%$ and $6 \%$, respectively, before transport. After the animals were loaded onto a vehicle and trucked for 30 to 40 minutes, the levels of Salmonella found in feces increased from $18 \%$ to $46 \%$, and the number of animals with contaminated hides escalated from $6 \%$ to $89 \%$ upon arrival at the slaughter plant. ${ }^{8}$ Fecal pathogens on the hide may then end up in the meat supply. ${ }^{8}$ Similar results were found in pigs ${ }^{9}$ and chickens raised for meat. ${ }^{10}$

Thorough cleaning of transport vehicles with disinfectants has been estimated to remove more than $95 \%$ of pathogens. ${ }^{11}$ In practice, however, a 2003 survey of livestock haulers found that only $16 \%$ of the 132 respondents indicated that they washed their transport vehicles between loads, and fewer than $5 \%$ used disinfectants as a component of the cleaning process. ${ }^{12}$ This may be attributed to the lack of written protocol provision by trucking companies on vehicle sanitation or, more likely, the lack of proper economic incentive for the truckers. ${ }^{13}$ An appreciation by buyers and sellers of the added value of the use of cleaned vehicles in the form of a potential reduction in both animal-disease losses and the incidence of foodborne pathogens may motivate the formation of compensation schemes for the time and expense required for proper sanitation.

\section{EpIZOOTICS}

Given the increased risk of spread and emergence of disease during shipping, the FAO blames " $\mathrm{t}]$ ransport of animals over long distances as one cause of the growing threat of 


\section{THE LONG HAUL: RISKS ASSOCIATED WITH LIVESTOCK TRANSPORT}

livestock epidemics. . . ."14 Historically, the advent of steam power during the Industrial Revolution allowed for the mass transport of cattle across long distances, which was blamed for an outbreak of a measleslike disease of clovenhoofed animals called rinderpest that destroyed most of the cattle in Europe between 1857 and 1866. ${ }^{15}$ The greatest animal plague ever recorded, however, was the "Great Rinderpest Pandemic" toward the end of the 19th century. The Italian army's use of cattle to pull gun carriages is blamed for the spread of the virus into sub-Saharan Africa, which resulted in the loss of up to $95 \%$ of cattle in some regions of Africa ${ }^{16}$ as well as up to $90 \%$ of other large ungulate species, such as the African buffalo and giraffe. ${ }^{15} \mathrm{Al}-$ though rinderpest has no zoonotic potential, ${ }^{17}$ societies based on the cattle economy were devastated. As one Masai man described the episode, the corpses of both cattle and humans were "so many and so close together that the vultures had forgotten how to fly." ${ }^{18}$ No longer can natural barriers like the Sahara fully protect populations against the spread of epidemic disease.

Of the diseases known to be transmitted by transportincluding classical swine fever, ${ }^{19}$ exotic Newcastle disease of birds, bovine viral diarrhea, African swine fever, swine dysentery, swine vesicular disease, porcine reproductive and respiratory syndrome, post-weaning multisystem wasting syndrome, porcine dermatitis and nephropathy syndrome, enzootic pneumonia, bovine rhinotracheitis, glanders, and sheep scabies ${ }^{2}$ - the American Veterinary Medical Association considers foot-and-mouth disease (FMD) to be the world's most economically devastating. ${ }^{20}$ Historically, dozens of outbreaks of FMD have been tied to livestock movements ${ }^{21}$ and contaminated transport vehicles. ${ }^{22}$

In the 1997 outbreak in Taiwan, 4 million pigs were infected, and $37.7 \%$ of the nation's pigs died or were killed, resulting in 65,000 jobs lost ${ }^{23}$ at an estimated cost of $\$ 6.6$ billion. $^{24}$ The Taiwan Council of Agriculture concluded that the outbreak was likely caused by the smuggling of infected animals from mainland China. ${ }^{25}$ An analysis of spatial and temporal patterns of FMD occurrence in Turkey, historically an important bridge between the endemic regions in Asia and disease-free Europe, showed a shift of predictors over the study period (1990-2002) away from short-distance spread between neighboring provinces toward large jumps ascribed to live animal transport over long distances. $^{26}$

Although the origin of the 2001 British FMD outbreak was blamed on the illegal importation of contaminated meat ${ }^{27}$ the subsequent explosive spread within the country was, according to the World Organization for Animal Health, "mainly attributed to the movement of subclinically infected animals, principally of sheep, and by contact with contaminated vehicles used for the transportation of these animals."22 A 1997 outbreak of classic swine fever in the Netherlands that spread to Italy, Spain, and Belgium was similarly linked to transport vehicles. ${ }^{18}$ The extensive spread facilitated by long-range transport not only makes easy eradication impossible but also undermines "regionalization." Regionalization allows for affected areas of a country to be risk-stratified independently, thereby limiting international trade losses that would otherwise mount should an entire country be broad-brushed with a single disease-affected status. ${ }^{28}$ Including tourism losses, the cost of the 2001 UK outbreak has been estimated at $\$ 20$ billion. $^{20}$

The further expansion of the 2001 British FMD outbreak into France was via the importation of infected sheep, and the spread of the disease into the Netherlands was traced to certified FMD-free calves imported from Ireland; the latter picked the virus up in transit at an overnight resting stop in France. ${ }^{29}$ Thus, live animal transport plays a significant role in both the spread and transmission of infectious disease.

\section{ZOONOSES}

As costly and disruptive as livestock disease outbreaks can be, long-distance live animal transport may also facilitate the spread of animal pathogens with the potential to cause human disease. The Nipah virus, for example, emerged in 1998 on an industrial pig farm in Malaysia to become one of the deadliest of human pathogens, causing relapsing brain infections and killing $40 \%$ of those infected. ${ }^{30}$ The disease erupted in the northern part of the Malaysian peninsula but was trucked nationwide. ${ }^{31}$ "A hundred years ago, the Nipah virus would have simply emerged and died out," the Thai Minister of Public Health explained. "Instead it was transmitted to pigs and amplified. With modern agriculture, the pigs are transported long distances to slaughter. And the virus goes with them."32

In the Malaysian outbreak, the Nipah virus took the lives of approximately 100 people. Avian influenza viruses have the potential to spawn pandemics capable of killing millions. ${ }^{33}$ In early 2004 , outbreaks of highly pathogenic avian flu strain H5N1 were reported nearly simultaneously across eight countries in Southeast Asia. Given the pattern and timing of outbreaks, the FAO identified the transport of live birds reared for human consumption as a primary culprit in the rapid spread. ${ }^{34}$ In February 2004, the FAO reported that 5,000 chickens had succumbed to avian influenza in Lhasa, Tibet, and that these infected birds had been transported to Tibet from China's Lanzhou city-a trip spanning more than 1,000 miles. ${ }^{35}$ The further the animals are transported, the further the diseases can spread. ${ }^{36}$

Long-distance live animal transport also has been blamed for the spread of swine flu viruses in the United States. Throughout much of the 20th century, influenza viruses had established a stable H1N1 lineage in U.S. pigs. That seemed to have changed in August 1998 when thousands of 
breeding sows fell ill on a North Carolina pig farm. An aggressive $\mathrm{H} 3 \mathrm{~N} 2$ virus was recovered, bearing the $\mathrm{H} 3$ and $\mathrm{N} 2$ antigens of the human influenza strain circulating since 1968. Not only was this highly unusual, but, upon sequencing of the viral genome, researchers found that it was not just a double reassortment (a hybrid of human and pig viruses, for example) but a never-before-described triple assortment, ${ }^{37}$ a hybrid of three viruses — a human virus, a pig virus, and a bird virus. "Within the swine population, we now have a mammalian-adapted virus that is extremely promiscuous," molecular virologist Richard Webby told Science. "We could end up with a dangerous virus."38

Within months, the virus appeared in Texas, Minnesota, and Iowa. ${ }^{37}$ Within one year, it had spread across the United States. ${ }^{39}$ The rapid dissemination across the nation was blamed on the cross-country transport of live pigs. ${ }^{38}$ In the U.S., pigs travel coast to coast: They are frequently born in North Carolina, fattened in the corn belt of Iowa, and then slaughtered in California. It is often cheaper to ship the animals to the feed rather than ship the feed to the animals. ${ }^{40}$ While this regional segmentation of production stages may cut down on short-term costs for the pork industry, the highly contagious nature of diseases like influenza-perhaps made even more infectious by the stresses of transport ${ }^{38}$ - must be considered when calculating the true cost of long-distance live animal transport.

\section{BIOTERRORISM}

According to the U.S. General Accountability Office (GAO), transporting live animals long distances may make countries vulnerable to bioterrorism as well. ${ }^{41}$ Over the past century, there has been a shift away from livestock production as a highly localized enterprise, where animals were typically born, fattened, and slaughtered in the same region. This change presents an opportunity for introduced pathogens to spread significant distances within a single incubation period-before a significant number of animals appear ill. ${ }^{42}$

This continuous cycle of mass animal movement may provide a built-in dispersal mechanism for bioterror agents. Inter-auction movements and intra-auction mixing also increase the potential for disease spread. ${ }^{40}$ Approximately 3,000 truckloads of cattle per day are being moved in the U.S. ${ }^{43}$ Rocco Casagrande, director of the Center for Homeland Security, has suggested that a terrorist could potentially infect nearly the entire U.S. cattle population by infecting just a few animals in the nation's major feedlots. ${ }^{44}$ In one FMD simulation described by the North Carolina Department of Agriculture, 8 days after an attack at a single location, as many as 23 million animals across 29 states could need to be destroyed..$^{45}$

The nefarious introduction of animal diseases is not just a theoretical concern. Veterinary historians have docu- mented at least a dozen attacks over the past century, starting with the first national biological warfare program, during World War I, ${ }^{45}$ in which German agents on three continents introduced anthrax and other livestock diseases. New York, Maryland, and Virginia were among the targets hit. ${ }^{46}$ During World War II, the Allies stockpiled 5,000,000 anthrax cakes that were to be spread over German pastures by parachute. The program was called "Operation Vegetarian." ${ }^{47}$ After World War II ended, the U.S. developed a number of biowarfare weapons, including cluster bombs filled with hog cholera or poultry virus-laden feathers that could be exploded at 1,500 feet. ${ }^{5}$ In the 1970 s, a major outbreak of anthrax in Rhodesia (now Zimbabwe) that infected more than 100,000 people and undermined the struggle there for independence has been considered "very likely intentional." 5 The movement of cattle during the outbreak was implicated in disease spread. ${ }^{48}$

U.S. animal agriculture has been described as a particularly easy $\operatorname{target}^{49}$ for economic attack ${ }^{50}$ as well as an assault on U.S. citizens. Part of this vulnerability derives from the industrial model of animal agriculture itself.

In 2004, the RAND Corporation prepared a report on agroterrorism for the Office of the Secretary of Defense titled, "Hitting America's Soft Underbelly," in which U.S. vulnerability was blamed in part on " $\mathrm{t}]$ he concentrated and intensive nature of contemporary U.S. farming practices." ${ }^{49}$ According to the last U.S. Department of Agriculture census in 2002, just $6 \%$ of the nation's hog farms produced three-quarters of the pigs and $2 \%$ of U.S. egg farms confined more than $90 \%$ of the nation's egg-laying hens. ${ }^{51}$ Given that "highly crowded" animals are reared in "extreme proximity" in the U.S., the RAND report describes how one infected animal could quickly expose thousands of others. ${ }^{49}$ Long-distance live animal transport could ferry a spreading infection to as many as 25 states within 5 days, according to USDA models. ${ }^{49}$

The response to biological threats in the U.S. has been described as "largely reactive, compartmentalized, and susceptible to impulsive congressional reactions." ${ }^{2}$ Many observers have noted that the agroterrorist threat hasn't garnered sufficient attention, ${ }^{45}$ but the situation seems to be improving. Although the 9/11 Commission (formally, the National Commission on Terrorist Attacks Upon the United States) did not make any direct references to agroterrorism in its report, ${ }^{53}$ Homeland Security Presidential Directive 9 (HSPD-9), "Defense of United States Agriculture and Food," released in 2004, specifically set out national policy to protect against terrorism targeting the food supply. ${ }^{54}$

Given the reported ease by which a single individual could disrupt a significant portion of the U.S. economy and potentially kill thousands and terrorize millions, ${ }^{55}$ former U.S. Department of Health and Human Services Secretary Tommy G. Thompson remarked in his farewell address: 


\section{THE LONG HAUL: RISKS ASSOCIATED WITH LIVESTOCK TRANSPORT}

"For the life of me, I cannot understand why the terrorists have not attacked our food supply, because it is so easy to do." ${ }^{56}$ Curtailing the long-distance live transport of animals as well as the concentration and intensification of the food animal industry could play an important role in mediating the impact of such an attack.

\section{TwENTY-EIgHT Hour LAW}

In the United States, the number of cattle, sheep, and pigs trucked interstate each year increased from 30 million animals in 1970 to 50 million in 2001, yet there has not been a concurrent rise in regulatory safeguards. ${ }^{40}$ Recognizing that "the health of animals is affected by the methods by which animals and articles are transported in interstate commerce and foreign commerce," the U.S. Animal Health Protection Act (AHPA) passed in 2002 gives the USDA broad authority to regulate interstate animal transport to prevent disease. ${ }^{57}$ To date, however, the agency has not implemented the act's mandate to comprehensively regulate interstate transport, instead focusing almost exclusively on the inspection of vehicles at national borders. ${ }^{58}$ Although this is an important component, especially given the drop in agricultural inspections when inspectors were transferred to the Department of Homeland Security (DHS) in 2002 (even while imports were increasing), ${ }^{41}$ domestic live animal transport may also have significant economic, public health, and national security implications.

The 42nd U.S. Congress passed a law regulating interstate animal transport in 1873. The "Twenty-Eight Hour Law" requires that "a rail carrier, express carrier, or common carrier . . . may not confine animals in a vehicle or vessel for more than 28 consecutive hours" without the animals being rested, watered, and fed. ${ }^{59}$ The terms "vehicle" and "common carrier" were not explicitly defined in the statute. The USDA interpreted the law to apply "only to rail shipments." ${ }^{60}$ As trucks now convey more than $95 \%$ of U.S. farm animals, ${ }^{61}$ by taking the position that " $\mathrm{t}]$ he Twenty-eight Hour Law does not apply to transport by truck," 62 the USDA essentially rendered the statute obsolete.

In response to a petition for rulemaking asking that "common carrier" and "vehicle" be defined to include truck transport in accordance with the plain meaning of these terms, ${ }^{63}$ the USDA reversed its decades-old stance in $2006,{ }^{64}$ conceding that trucks were indeed "vehicles" and therefore covered under the law. ${ }^{65}$ It is now up to the USDA to investigate violations and assist the Department of Justice in prosecutions. ${ }^{65}$

\section{MAIL-ORder ChICKENS}

Rulemaking petitioners also asked that birds be defined as "animals" under the statute. Despite the epizootic and zoonotic potential of avian diseases, the USDA administrator wrote in 2006 that " $[\mathrm{t}]$ he Twenty-Eight Hour Law was never construed as being applicable to poultry, and . . . USDA does not intend to change this longstanding interpretation of the statute." ${ }^{\prime 65}$ Although some poultry are transported long distances, ${ }^{66}$ there are few publicly available statistics, probably because of the extensive vertical integration of the U.S. poultry industry. ${ }^{67}$ Millions of live birds are reportedly shipped through the mail, however, via the U.S. Postal Service (USPS) every year. ${ }^{68}$

The GAO, in its June 2007 report on USDA avian influenza preparedness efforts, questioned this practice, raising concerns that many birds entering states through the mail may be illegally undocumented and potentially diseased. The report documents that North Carolina agriculture officials found that, of the more than 5,000 birds entering the state via three postal facilities over a 9-day period in $2003,72 \%$ were missing necessary health documentation. Furthermore, birds lacking health certification were kept in the same room as birds cleared of disease, raising the possibility of disease spread to birds that had been certified healthy. In August 2005, the North Carolina Department of Agriculture Food and Drug Safety administrator reportedly told a gathering of federal and state officials that current USPS regulations "are inadequate and present great potential for contamination of the poultry industry." 69

Department of Homeland Security and state officials told the GAO that this problem also exists on commercial airlines that transport birds. ${ }^{70}$ Shipping industry lobbying efforts have blocked attempts by airline carriers, however, to refuse live bird shipments. When several airlines announced plans to halt shipments of live poultry, the Senate, at the behest of the trade group Bird Shippers of America, tacked a provision onto a 2001 appropriations bill allowing the USPS to require airlines to carry live birds. ${ }^{68}$ Airlines found loopholes through which they could continue to decline shipments of live poultry, ${ }^{71}$ so a bill was introduced in the Senate in 2006 to force their compliance. ${ }^{72}$ Given the concerns recently voiced to the GAO over the risks of disease transmission in this context, rescinding the current requirement for airlines to accept live birds rather than bolstering the policy may be more prudent.

\section{ECONOMIC LOSSES}

Although live animal transport regulations may be costly in the short-term, David Byrne, the former European Commissioner for Health and Consumer Protection, said that he remained "convinced that the longer-term gains, in terms of increased bio-security and healthier animals, will reap greater economic rewards into the future." 73 In the short term, transport costs may be relatively low compared to production costs, such as the cost of land and labor, 
which consequently may play a greater role in determining location and market segmentation. But the low private expense of transport may rarely factor in the associated social, environmental, and disease costs. ${ }^{74}$ Limiting live animal transport may not allow only for good animal health and welfare but for good economics as well. ${ }^{75}$

The costs associated with transport extend well beyond direct freight charges. ${ }^{76}$ Data from the National Institute for Animal Agriculture suggest that 80,000 pigs die annually in the U.S. during the transportation process. Assuming a $\$ 100$ market value per hog, this equates to an $\$ 8$ million annual loss to the pork industry, not including carcass disposal fees. ${ }^{77}$ Beyond death losses, nonambulatory ("downer") pigs at the slaughter plant may be severely discounted and require additional labor handling costs, and carcass trim loss due to transport-related bruising and other pork quality defects may pose additional cost burdens. ${ }^{78}$ Increasing transport floor space may significantly reduce both the percentage of nonambulatory pigs and total losses (dead and disabled), ${ }^{79}$ and gentler handling techniques during loading and unloading (plastic canes compared to electric prods) may reduce stress-related disability. ${ }^{80}$

Cattle mortality is relatively rare in transit, but transportation-associated loss of mobility has proven to be a costly problem. In 1999 the losses associated with the additional handling of nonambulatory cattle were valued at $\$ 0.56$ for every cow and bull marketed. ${ }^{81}$ With most disabled cattle now excluded from the U.S. food supply as a result of the discovery of bovine spongiform encephalopathy in the U.S. in $2003,{ }^{82}$ the USDA estimates zero salvage value for these "downer" animals, with the possibility of added disposal costs. ${ }^{83}$

In addition to production losses to disease, carcass characteristics may suffer. Inanition (exhaustion due to lack of nourishment) associated with transport is likely an important cause of carcass and meat quality depreciation. Broken bones, bruising, blood spots, and lacerations from transport may lead to carcass downgrading. ${ }^{84}$ Bruising alone has been estimated to cause more than $\$ 100$ million in annual economic losses. ${ }^{85}$ Preslaughter stress may result in paler chicken thigh meat ${ }^{86}$ and tougher rabbit leg meat ${ }^{87}$ and can contribute to the formation of dark, firm, and dry meat in beef and pale, soft, and exudative meat in pork. ${ }^{88}$ Epinephrine infusion in pigs significantly perturbs the calpain enzyme system thought to be involved in myofibrillar protein degradation, a determinant of meat tenderization rates, raising the possibility that transport stress may result in tougher meat. ${ }^{89}$ Similar results have been found in bovine $e^{90}$ and ovine ${ }^{91}$ muscle in response to $\beta$-adrenergic agonist agent exposure. Transport has been shown to have a negative impact on beef ${ }^{92}$ and veal ${ }^{93}$ palatability attributes in general, but a sensory panel could not differentiate ham juiciness or desirability based on duration of transport. ${ }^{94}$

Long-distance transport can also lead to a reduction of slaughter yield, an effect which may be only partially explained by fasting. ${ }^{95}$ Much of the loss is from carcass components and not simply gastrointestinal fill. ${ }^{96}$ Pigs transported for 11 hours may lose a commercially significant 3\% of their body weight; ${ }^{94}$ sheep transported for 18 hours may suffer as much as an $8 \%$ mean loss of live weight; ${ }^{97}$ and the transport and holding of goats may result in a $10 \%$ loss of live weight. ${ }^{98}$ Live-hauling broilers also results in carcass shrinkage, thought largely attributable to energy expenditure related to convective heat loss during transport. ${ }^{99}$

There also may be nonfinancial benefits to a reduction in the transport of livestock. The livestock sector is coming under increasing scrutiny as a contributor to greenhouse gas emissions. ${ }^{100}$ Measured in $\mathrm{CO}_{2}$ equivalent, the FAO estimates that animal agriculture is responsible for $18 \%$ of worldwide emissions, a higher share than the global transportation sector, ${ }^{74}$ leading critics to recommend a reduction in global meat consumption. ${ }^{101}$ Although this figure includes the transport of feed and the final processed animal product, it does not take into account the $\mathrm{CO}_{2}$ emissions attributable to the transport of live animals. ${ }^{74}$ To offset their carbon footprint, industry leaders Cargill ${ }^{102}$ and Smithfield ${ }^{103}$ have both recently joined the Chicago Climate Exchange, the world's first voluntary, legally binding reduction, registry, and trading program for greenhouse gas emissions. The livestock sector may be able to more cost-effectively buffer criticism in this area by publicly announcing reductions in long-distance transport, compared to less easily mitigated discharges such as enteric ruminant methane production.

There also seems to be an emerging social ethic regarding farm animal welfare. ${ }^{104}$ A 2003 Gallup poll found that $62 \%$ of Americans sampled support "[p]assing strict laws concerning the treatment of farm animals." 105 A 2003 Zogby poll estimated that two-thirds of Americans find it "unacceptable" that many state anti-cruelty statutes exempt standard farming practices and, separately, that no federal laws address on-farm treatment of farm animals. Nearly threequarters of respondents believe that farms ought to be inspected by government officials to ensure that anti-cruelty regulations are being followed. ${ }^{106}$

The nature of live animal transport requires open-sided trucks or ventilatory openings, which may offer many urban Americans an emotive glimpse of modern farm animal production. Highway accidents, ${ }^{107}$ nonambulatory livestock, ${ }^{78}$ and investigations of transport conditions ${ }^{108}$ threaten to garner negative media attention for the livestock industry. By proactively addressing farm animal welfare concerns through self-regulating the extent of live animal transport, U.S producers may improve consumer perceptions and challenge efforts to undermine industry autonomy via the imposition of new legislative restrictions. ${ }^{104}$ Perceived higher welfare animal products may also add value and command premium prices. $^{75}$ 


\section{The European Aprroach}

Long-distance animal transport is restricted in Europe to a duration ranging from 9 to 24 hours, with either continuous access to water or watering every 8 to 14 hours, depending on species. ${ }^{109}$ In 2001, the European Parliament adopted by a large majority a resolution calling for the limitation of live animal transport to a maximum duration of 8 hours for all species. ${ }^{110}$ Although an 8 -hour limit was rejected by the European Health and Consumer Protection Commissioner, ${ }^{73}$ further restrictions on travel times (and animal densities) are expected to be announced before 2010. ${ }^{111}$ Canada is likewise working toward reducing feed, water, and rest intervals as well as loading densities. ${ }^{112}$

In the European Community, 365 million head of livestock (not including poultry) are transported every year. ${ }^{110}$ The trend toward shipping live animals long distances within the EU has been accelerated by the formation of the single market. Sheep, for example, are now routinely sent from the UK to Italy, Greece, and Spain for slaughter; pigs are exported from the Netherlands to Spain and Italy for fattening; and cattle leave Germany, Ireland, and France for transport to the Middle East and North Africa, a practice subsidized by export refunds. ${ }^{113}$ The FAO has warned that this opening of live trade routes throughout Europe and the Near East could facilitate the spread of animal disease. ${ }^{114}$

The establishment of staging areas in Europe, at which animals can be unloaded to rest, have the potential to be counterproductive if adequate attention is not given to appropriate handling and biosecurity. Even if staging points, markets, and vehicles are properly cleaned and disinfected and animal groups are not mixed, frequent loading and unloading may increase stress, the risk of injuries, and the risk of disease transmission. Alternatives include properly equipped on-vehicle feeding, resting, and watering, provided that the loading densities are appropriately low. ${ }^{115}$

Reducing the overall duration of the journeys may be preferable to simply increasing the frequency of watering, feeding, and resting opportunities. In 2005, the 167 member countries of the Office International des Epizooties (World Organization for Animal Health) adopted animal transport standards, ${ }^{116}$ the first article of which reads: "The amount of time animals spend on a journey should be kept to the minimum."117 This echoes the conclusions of the European Commission's Scientific Committee on Animal Health and Animal Welfare and the European Food Safety Authority that "journeys should be as short as possible." 115,118 Situating breeding facilities closer to feed and forage crop availability and increasing the number and regional distribution of smaller-scale nonspecies-specific processing plants could help achieve this end. The transport of semen and embryos may also replace in part the transport of animals for breeding purposes. ${ }^{115}$
The Federation of Veterinarians of Europe has stated that it has "always been of the opinion that the fattening of animals should take place within or near the place of birth" and that "[a]nimals should be slaughtered as near the point of production as possible." ${ }^{2}$ Regional abattoirs may also support local food economies and minimize environmental "food miles." The savings on live animal shipping costs associated with packing plant decentralization can help offset assembly costs and diminished economies of scale. ${ }^{119}$ The FAO encourages the establishment of uninterrupted "cold chains" of refrigeration from slaughter plant to supermarket in developing countries to reduce the disease risks associated with live animal transport and live animal market systems, but this is contingent on consumer acceptance of chilled meat. ${ }^{120}$

Although physiologic indicators show that animals in transit become increasingly compromised with time, for some species journey duration may be less of a problem than the conditions under which they are traveling, such as loading density, vehicle design, and driving behavior. ${ }^{121} \mathrm{Al}-$ though the latest EU transport regulations do not further restrict trip duration, they do include many important refinements.

The key improvements expected with the new policy, which went into effect January 2007, center on better education of key stakeholders - the animal attendants, drivers, and transport organizers - and stricter control mechanisms, such as the fitting of vehicles with satellite positioning devices to track animal movements and check compliance with travel times and rest periods. ${ }^{122}$ Mandatory improvements in vehicular design, such as the capacity for mechanical ventilation on long trips, are also expected to help minimize stress. ${ }^{116}$ With advances in technological innovation and affordability, it may soon be possible to equip transport vehicles with control systems to continuously monitor physiologic indicators such as heart rate and body temperature, climatic conditions onboard, and even vehicular vibration and movement for recording or transmission. ${ }^{123}$

The importance of the basic education and training component, however, should not be underestimated. Many drivers of livestock conveyances are unaware that rapid braking or even the lateral acceleration around curves readily accepted by human passengers can increase stress and injury risk by throwing animals to the floor. ${ }^{115}$ Just as drivers of hazardous materials are required to complete specialized instruction, under the new EU rules truckers are subject to compulsory training and certification in careful driving and animal handling techniques. ${ }^{109}$

Payment schemes involving bonuses or penalty deductions have also been shown to successfully improve driving behavior. ${ }^{115}$ For example, those receiving extra pay for reducing fuel usage were found to drive more slowly with gentler accelerations, resulting in a measurable improvement in animal welfare. ${ }^{124}$ Similarly, when pay has been 
tied to resulting meat quality, researchers have documented diminished evidence of trauma, such as bruising and bone breakages, and fewer dead-on-arrival animals. ${ }^{125}$ The Scientific Committee on Animal Health and Animal Welfare has expressed opposition to allowing transporters to obtain insurance against mortality losses and poor carcass quality, as this might undermine incentives to decrease stressors. ${ }^{115}$

\section{DRIVING FORWARD}

It is uncertain whether the regulatory changes taking place in Europe and elsewhere could be cost-effectively applied in the United States. In 2006 the U.S. National Academy of Sciences published guidelines for the humane transportation of animals used in research. ${ }^{126}$ A similar National Research Council review of farm animal transport could provide science-based guidance of particular relevance to U.S. producers and policymakers. In Europe, for example, the nontherapeutic use of antibiotics in agriculture is more restricted than it is in the U.S. The mass prophylaxis of cattle with penicillin, ${ }^{127}$ tetracycline, and sulfa drug antibiotic classes ${ }^{128}$ has been shown to reduce the incidence of transport stress-induced respiratory disease, although use must be prudently balanced with the risk for the emergence and spread of antimicrobial resistance. ${ }^{129}$

International conferences and workshops addressing livestock transport organized in recent years by the American Meat Institute Foundation, ${ }^{130}$ the Animal Transportation Association, ${ }^{131}$ the OIE, ${ }^{132}$ the European Commission, and others ${ }^{133}$ represent another avenue by which regulatory experiences can be shared, research priorities established, and international guidelines standardized. Although broad consensus seems to exist on certain key animal transport issues, ${ }^{134}$ space allowance guidelines, for example, vary greatly from country to country. Comparing current recommendations and regulations in the U.S., the EU, the UK, Ireland, South Africa, Australia, and New Zealand for minimum space allotments for pigs, for example, Bench and colleagues noted that South Africa recommends the least amount of space per transported pig $\left(0.30 \mathrm{~m}^{2} / 100 \mathrm{~kg}\right)$, whereas the U.S. recommends the most $\left(0.50 \mathrm{~m}^{2} / 100\right.$ $\mathrm{kg}){ }^{134}$ Recommendations from Canada $\left(0.36 \mathrm{~m}^{2} / 100 \mathrm{~kg}\right)$ and the EU and Ireland $\left(0.425 \mathrm{~m}^{2} / 100 \mathrm{~kg}\right)$ fall into the range suggested by some studies on posture during transport-greater than $0.36 \mathrm{~m}^{2} / 100 \mathrm{~kg}$ but not to exceed 0.425 $\mathrm{m}^{2} / 100 \mathrm{~kg} .{ }^{134}$

There are several areas requiring further study. For each animal species and gender, there is still much to learn about optimal stocking densities, resting schedules, and ventilation requirements. The interaction of stressors - transport fatigue, food and water deprivation, and environmental factors such as vibration, motion, and light-is also poorly understood $^{115}$ but can be investigated with a combination of clinical, physiological, biochemical, and behavioral reaction measurements. ${ }^{122}$ A retrospective study of the role animal transport has played in past outbreaks may further elucidate the mechanisms and pathways of pathogen transmission. ${ }^{115}$ No comprehensive research exists, for example, on the bioaerosol and particulate emissions from driving and standing animal transport vehicles. A cross-cultural study of the socioeconomic reasons for continued live animal transport in the age of refrigeration would also be of value. ${ }^{115}$

A complete ban on long-distance live animal transport may not be tenable, ${ }^{73}$ as there may always be the long-distance transport of specialized livestock (breeding stock and racehorses, for example), ${ }^{135}$ but tighter regulations and a transition toward a carcass-only trade may mediate the potentially serious public health implications of epizootics, whether natural or intentional, and have additional positive social and economic benefits. The FAO projects worldwide annual meat production to double by $2050 .^{74}$ As farm animal production continues to increase on a global scale, recent developments in Europe and elsewhere may represent the first steps toward that goal.

\section{REFERENCES}

1. Food and Agriculture Organization of the United Nations. FAO Animal Production and Health Paper 153: Improved Animal Health for Poverty Reduction and Sustainable Livelihoods. Rome: FAO; 2002. http://www.fao.org/documents/ show_cdr.asp?url_file=/docrep/005/y3542e/y3542e00.htm. Accessed May 2007.

2. Federation of Veterinarians of Europe. Transport of Live Animals. FVE Position Paper. FVE/01/043. Brussels: FVE; 2001. http://fve.org/papers/pdf/aw/position_papers/01_043. pdf. Accessed May 2007.

3. Shields DA, Mathews KH Jr. U.S. Department of Agriculture Economic Research Service. Interstate Livestock Movements 2. Washington, DC: USDA; 2003. http://ers.usda. gov/publications/ldp/jun03/ldpm10801/ldpm10801.pdf. Accessed May 2007.

4. American Meat Institute. Fact Sheet: Overview of U.S. Meat and Poultry Production and Consumption. 2004.

5. Wilson TM, Logan-Henfrey L, Weller R, Kellman B. Agroterrorism, biological crimes, and biological warfare targeting animal agriculture. In: Brown C, ed. Emerging Diseases of Animals. Washington, DC: ASM Press; 2000:23-57.

6. Food and Agriculture Organization of the United Nations. Guidelines for Humane Handling, Transport and Slaughter of Livestock. Bangkok: FAO; 2001. http://www.fao.org/ DOCREP/003/X6909E/x6909e08.htm. Accessed May 2007.

7. Pharmacia Animal Health. Beef Health Management, Bovine Respiratory Disease (BRD) (Pneumonia, Shipping Fever, Cattle Respiratory Syndrome [CRS], Travel Fever). http://excenel.com/Health.asp?country=UK\&lang=EN\&sp ecies=BF\&drug=EP\&index=601. Accessed May 2007.

8. Barham AR, Barham BL, Johnson AK, Allen DM, Blanton JR Jr, Miller MF. Effects of the transportation of beef cattle 


\section{THE LONG HAUL: RISKS ASSOCIATED WITH LIVESTOCK TRANSPORT}

from the feedyard to the packing plant on prevalence levels of Escherichia coli 0157 and Salmonella spp. J Food Prot 2002;65:280-283.

9. Marg H, Scholz HC, Arnold T, Rosler U, Hensel A. Influence of long-time transportation stress on reactivation of Salmonella Typhimurium DT 104 in experimentally infected pigs. Berliner und Munchener tierarztliche Wochenschrift 2001;114:385-388.

10. Whyte P, Collins JD, McGill K, Monahan C, O’Mahony $\mathrm{H}$. The effect of transportation stress on excretion rates of Campylobacter in market-age broilers. Poult Sci 2001;80(6): 817-820.

11. Barrington GM, Gay JM, Evermann JF. Biosecurity for neonatal gastrointestinal diseases. Vet Clin North Am Food Anim Pract 2002;18:7-34.

12. Spire M. Kansas trucking survey results. Program of the Kansas Transport Initiative Workshop, College of Veterinary Medicine, Kansas State University, Manhattan, KS; 2004:1-3.

13. Fike K, Spire MF. Transportation of cattle. Vet Clin North Am Food Anim Pract 2006;22:305-320.

14. Food and Agriculture Organization of the United Nations. News and highlights: Europe vulnerable to livestock epidemics, warning delivered at FAO press conference. February 17, 1998. http://www.fao.org/news/1998/980204-e. htm. Accessed May 2007.

15. Torres A. International economic considerations concerning agricultural diseases and human health costs of zoonotic diseases. Ann N Y Acad Sci 1999;894(1):80-82.

16. Phoofolo P. Face to face with famine: the BaSotho and the Rinderpest, 1897-1899. J South Afr Stud 2003;29: 503-527.

17. Barrett T, Rossiter PB. Rinderpest: the disease and its impact on humans and animals. Adv Virus Res 1999;53: 89-110.

18. Plowright W. The effect of rinderpest and rinderpest control on wildlife in Africa. In: Animal Diseases in Relation to Animal Conservation. London: Symposium of the Zoological Society of London; 1982:1-28.

19. Elbers AR, Moser H, Ekker HM, et al. Tracing systems used during the epidemic of classical swine fever in the Netherlands 1997-1998. Rev Sci Tech 2001;20(2):614-29. http:// www.oie.int/eng/publicat/rt/2002/elbers.pdf. Accessed May 2007.

20. American Veterinary Medical Association. Foot and mouth disease. 14 February 2007. http://www.avma.org/reference/ backgrounders/fmd_bgnd.pdf. Accessed July 2007.

21. U.S. Department of Agriculture Animal and Plant Health Inspection Service Centers for Epidemiology and Animal Health. Foot and Mouth Disease: Sources of Outbreaks and Hazard Categorization of Modes of Virus Transmission. Washington, DC: USDA; December 1994.

22. World Organization for Animal Health/Food and Agriculture Organization of the United Nations. International Scientific Conference on Foot and Mouth Disease; Paris; 17-18 April 2001. ftp://ftp.oie.int/FMD20010417-18/ OIEFAO_conf.pdf. Accessed May 2007.

23. Yang PC, Chu RM, Chung WB, Sung HT. Epidemiological characteristics and financial costs of the 1997 foot-andmouth disease epidemic in Taiwan. Vet Rec 1999;145(25): 731-734.
24. Food and Agriculture Organization of the United Nations. Animal diseases: implications for international meat trade. Nineteenth session of the intergovernmental group of meat and dairy products. Rome; 27-29 August 2002.

25. Food and Agriculture Organization of the United Nations. FMD Situation in Europe and other regions in 1999. http://www.fao.org/AG/AGAINFO/commissions/en/eufm d/app/63/app01.html. Accessed July 2007.

26. Gilbert M, Aktas S, Mohammed H, et al. Patterns of spread and persistence of foot-and-mouth disease types $\mathrm{A}, \mathrm{O}$ and Asia-1 in Turkey: a meta-population approach. Epidemiol Infect 2005;133(3):537-545.

27. United Kingdom House of Commons Library Science and Environment Section. Foot and mouth disease. Research Paper 01/35. 27 March 2001. http://www.parliament.uk/ commons/lib/research/rp2001/rp01-035.pdf. Accessed July 2007.

28. Seitzinger AH, Forsythe KW Jr, Madell ML. Regionalization's potential in mitigating trade losses related to livestock disease entry. Ann N Y Acad Sci 1999;894:95-99.

29. Pluimers FH, Akkerman AM, van der Wal P, Dekker A, Bianchi A. Lessons from the foot and mouth disease outbreak in The Netherlands in 2001. Rev Sci Tech 2002;21(3):711-721.

30. Uppal PK. Emergence of Nipah virus in Malaysia. Ann NY Acad Sci 2000;916:354-357.

31. Smith S. Crossing the species barrier from AIDS to Ebola, our most deadly diseases have made the leap from animals to humans. Boston Globe April 29, 2003:C1.

32. Specter M. Nature's bioterrorist. New Yorker February 28, 2005:52-61.

33. Murray CJ, Lopez AD, Chin B, Feehan D, Hill KH. Estimation of potential global pandemic influenza mortality on the basis of vital registry data from the 1918-20 pandemic: a quantitative analysis. Lancet 2006;368(9554):2211-2218.

34. Food and Agriculture Organization of the United Nations. Animal health special report: avian influenza questions and answers. 2004

35. Food and Agriculture Organization of the United Nations. Update on the avian influenza situation 5. February 25, 2004.

36. European Commission Health and Consumer Protection Directorate General. The welfare of animals during transport, 14-19. Adopted March 11, 2002:152.

37. Zhou NN, Senne DA, Landgraf JS, et al. Genetic reassortment of avian, swine, and human influenza A viruses in American pigs. J Virol 1999;73:8851-8856.

38. Wuethrich B. Infectious disease: chasing the fickle swine flu. Science 2003;299:1502-1505.

39. Webby RJ, Swenson SL, Krauss SL, Gerrish PJ, Goyal SM, Webster RG. Evolution of swine H3N2 influenza viruses in the United States. J Virol 2000;74:8243-8251.

40. USDA Economic Research Service. Interstate Livestock Movements. LPD-M-108-01. June 2003. http://www.ers. usda.gov/publications/ldp/jun03/ldpm10801/. Accessed July 2007.

41. U.S. Government Accountability Office. Report to Congressional Requesters. Homeland Security: Much Is Being Done to Protect Agriculture from a Terrorist Attack, but Important Challenges Remain. Washington, DC: GAO; March 2005. http://www.gao.gov/new.items/d05214.pdf. Accessed May 2007. 
42. Dunn MV. The threat of bioterrorism to U.S. agriculture. Ann N Y Acad Sci 1999;894(1):184-188.

43. Crews J. Handle with care. Food Systems Insider 1 March 2004. http://www.foodsystemsinsider.com/ME2/dirmod. asp?sid=62E1B3791A924B86B1C3329642224C1C\&nm= Articles\&type $=$ Publishing\&mod $=$ Publications $\% 3 \mathrm{~A} \% 3 \mathrm{AAr}-$ ticle\&mid=8F3A7027421841978F18BE895F87F791\&tier $=4 \& \mathrm{id}=79 \mathrm{CC} 6 \mathrm{~B} 278 \mathrm{~B} 374 \mathrm{ED} 380 \mathrm{EC} 2 \mathrm{~B} 2 \mathrm{AC} 6 \mathrm{C} 66853$. Accessed November 2, 2007.

44. Casagrande R. Biological warfare targeted at livestock. BioScience 2002;52(7):577-581.

45. Monke J. Agroterrorism: Threats and Preparedness. Washington, DC: Congressional Research Service; August 13, 2004 www.fas.org/irp/crs/RL32521.pdf. Accessed November 2, 2007.

46. Koczura R, Kaznowski A, Mickiewicz A. The potential impact of using biological weapons against livestock and crops. Applied Science and Analysis Newsletter 2002;04-6(105). http://asanltr.com/newsletter/04-6/articles/046c.htm. Accessed May 2007.

47. Wilson TM, Gregg DA, King DJ, et al. Agroterrorism, biological crimes, and biowarfare targeting animal agriculture: the clinical, pathologic, diagnostic, and epidemiologic features of some important animal diseases. Clin Lab Med 2001;21:549-591.

48. Davies JCA. A major epidemic of anthrax in Zimbabwe. Cent Afr J Med 1983;29(1):8-12.

49. Chalk P. Hitting America's Soft Underbelly: The Potential Threat of Deliberate Biological Attacks Against the U.S. Agricultural and Food Industry. Prepared for the Office of the Secretary of Defense. Santa Monica, CA: RAND National Defense Research Institute; 2004. http://rand.org/pubs/ monographs/2004/RAND_MG135.pdf. Accessed May 2007.

50. Ishmael W. A soft underbelly. Beef 1 July 2003:11.

51. U.S. Department of Agriculture. U.S. National Level Data. In: Census of Agriculture. Vol 1. Washington, DC: USDA; 2002: Chap 1. http://www.nass.usda.gov/census/census02/ volume1/us/index1.htm. Accessed May 2007.

52. Frazier TW. Natural and bioterrorist/biocriminal threats to food and agriculture. Ann N Y Acad Sci 1999;894:1-8.

53. National Commission on Terrorist Attacks upon the United States. The 9/11 Commission Report. July 2004. http://www.9-11 commission.gov/report/911Report.pdf. Accessed July 2007.

54. Homeland Security Presidential Directive/HSPD-9. http:// www.whitehouse.gov/news/releases/2004/02/200402032.html. Accessed July 2007.

55. Wein LM, Liu Y. Analyzing a bioterror attack on the food supply: the case of botulinum toxin in milk. Proc Natl Acad Sci U S A 2005;102:9984-9989.

56. Nesmith J, McKenna MAJ. Health chief s exit has warning. Atlanta Journal-Constitution December 4, 2004:1A.

57. 7 U.S.C. $\$ 8301(3)(2005)$.

58. See, e.g., 9 C.F.R. $\$ \$ 93.201,93.301,93.401,93.501$ (2004)

59. 49 U.S.C. $\$ 80502$.

60. U.S. Department of Agriculture, Agriculture Marketing Service. Cattle and Swine Trucking Guide for Exporters. May 1997. http://www.ams.usda.gov/tmd/livestock/Truck\%20 Guide.htm\#N_10_. Accessed July 2007.

61. U.S. Department of Transportation, Bureau of Transportation Statistics. Shipment characteristics by two-digit com- modity and mode of transportation for the United States: 2002, SCTG Code: 01-SCTG Description (2-digit): Live animals and live fish. 2002.

62. 60 Fed. Reg. 48362, 48365 (Oct. 19, 1995).

63. Snelson H. USDA concedes the 28-hour law applies to trucks. Amer Assoc Porcine Veterinarians News 4 October 2006. http://www.aasp.org/news/story.php?id=2083. Accessed May 2007.

64. 9 C.F.R. $\$ 89.1-89.5$ (promulgated in 28 Fed. Reg. 5967 , June 13, 1963).

65. Cohen H. Brief Summaries of Federal Animal Protection Statutes. Washington, DC: Congressional Research Service; 11 January 2007. http://www.nationalaglawcenter.org/ assets/crs/94-731.pdf. Accessed July 2007.

66. Newberry RC, Webster AB, Lewis NJ, Van Arnam C. Management of spent hens. J Appl Anim Welf Sci 1999;2(1) $13-29$.

67. U.S. Department of Agriculture, Economic Research Center. Poultry and Eggs: Background. Updated May 3, 2006. http://www.ers.usda.gov/briefing/poultry/background.htm. Accessed July 2007

68. Spurgeon D, Power S. Lawmakers pass bill forcing airlines to transport chicks at bargain fares. Wall Street Journal 7 November 2001.

69. Pacelle W. Testimony before the Subcommittee on Crime, Terrorism, and Homeland Security on the subject of H.R. 137. 6 February 2007. http://judiciary.house.gov/Hearing Testimony.aspx?ID=499. Accessed July 2007 .

70. U.S. Government Accountability Office. Avian Influenza: USDA Has Taken Important Steps to Prepare for Outbreaks, but Better Planning Could Improve Response. Washington, DC: GAO; June 2007. http://www.gao.gov/new.items/ d07652.pdf. Accessed July 2007.

71. Congressional Record. Senate: statements on introduced bills and joint resolutions. 9 March 2006, p. S1967.

72. S.2395. http://thomas.loc.gov/cgi-bin/bdquery/z?d109: SN02395:

73. Byrne D. Animal transport: improvement on the way. Annual General Meeting of the Veterinary Officers Association of Ireland; April 4, 2003; Tullamore. http://europa.eu/ $\mathrm{rapid} /$ pressReleasesAction.do?reference=SPEECH/03/182 $\&$ format $=$ HTML\&aged $=0$ \&language $=$ EN \& guiLan guage $=$ en. Accessed July 2007.

74. Steinfeld H, Gerber P, Wassenaar T, Castel V, Rosales M, de Haan C. Livestock's Long Shadow: Environmental Issues and Options. Rome: Food and Agriculture Organization; 2006:61.

75. Harris T. Animal transport and welfare: a global challenge. Rev Sci Tech 2005;24:647-653.

76. Speer NC, Slack G, Troyer E. Economic factors associated with livestock transportation. J Anim Sci 2001;79: E166-E170.

77. Grandin T. Livestock Trucking Guide: Livestock Management Practices that Reduce Injuries to Livestock during Transport. Bowling Green, KY: Livestock Conservation Institute; 1992.

78. Ellis M, McKeith F, Hamilton D, Bertol T, Ritter M. Analysis of the current situation: What do downers cost the industry and what can we do about it? Proceedings of the 4th American Meat Science Association Pork Quality Symposium, Columbia, MO 2003.

79. Ritter MJ, Ellis M, Brinkmann J, et al. Effect of floor space during transport of market-weight pigs on the incidence of 


\section{THE LONG HAUL: RISKS ASSOCIATED WITH LIVESTOCK TRANSPORT}

transport losses at the packing plant and the relationships between transport conditions and losses. J Anim Sci 2006;84:2856-2864.

80. Benjamin ME, Gonyou HW, Ivers DJ, et al. Effect of animal handling method on the incidence of stress response in market swine in a model system. J Anim Sci 2001;79:279s.

81. Smith GC, Belk KE, Tatum JD, et al. National Market Cow and Bull Beef Quality Audit. Englewood, CO: National Cattlemen's Beef Association; 2000.

82. 9 C.F.R. Parts 309,310 and 318.

83. U.S. Department of Agriculture, Food Safety and Inspection Service, Office of Policy and Program Development. Preliminary Analysis of Interim Final Rules and an Interpretive Rule to Prevent the BSE Agent from Entering the U.S. Food Supply. Washington, DC: U.S. Department of Agriculture; 2004.

84. Guise J, Penny RHC. Factors affecting the welfare, carcass and meat quality of pigs. Animal Production 1989;49: 517-521.

85. Boleman SL, Boleman SJ, Morgan WW, et al. National Beef Quality Audit-1995: survey of producer-related defects and carcass quality and quantity attributes. J Anim Sci 1998;76:96-103.

86. Kannan G, Heath JL, Wabeck CJ, Souza MC, Howe JC, Mench JA. Effects of crating and transport on stress and meat quality characteristics in broilers. Poult Sci 1997;76:523-529.

87. Lambertini L, Vignola G, Badiani A, Zaghini G, Formigoni A. The effect of journey time and stocking density during transport on carcass and meat quality in rabbits. Meat Sci 2006;72:641-646.

88. Lawrie RA. Metabolic stresses which affect muscle. In: Briskey EJ, Cassens RG, Trautman JC, eds. The Physiology and Biochemistry of Muscle as Food. Madison, WI: University of Wisconsin Press; 1966:137-164.

89. Sensky PL, Parr T, Bardsley RG, Buttery PJ. The relationship between plasma epinephrine concentration and the activity of the calpain enzyme system in porcine longissimus muscle. J Anim Sci 1996;74:380-387.

90. Wheeler TL, Koohmaraie M. Effects of the beta-adrenergic agonist L644,969 on muscle protein turnover, endogenous proteinase activities, and meat tenderness in steers. J Anim Sci 1992;70:3035-3043.

91. Pringle TD, Calkins CR, Koohmaraie M, Jones SJ. Effects over time of feeding a beta-adrenergic agonist to wether lambs on animal performance, muscle growth, endogenous muscle proteinase activities, and meat tenderness. J Anim Sci 1993;71:636-644.

92. Schaefer AL, Jones SDM, Tong AKW, Young BA. Effects of transport and electrolyte supplementation on ion concentrations, carcass yield and quality in bulls. Can J Anim Sci 1990; 70:107.

93. Fernandez X, Monin G, Culioli J, Legrand I, Quilichini Y. Effect of duration of feed withdrawal and transportation time on muscle characteristics and quality in Friesian-Holstein calves. J Anim Sci 1996;74:1576-1583.

94. Becker BA, Mayes HF, Hahn GL, et al. Effect of fasting and transportation on various physiological parameters and meat quality of slaughter hogs. J Anim Sci 1989;67:334-341.

95. Knowles TG, Warriss PD, Brown SN, et al. Long distance transport of lambs and the time needed for subsequent recovery. Vet Rec 1993;133:286-293.
96. Jones SDM, Schaefer AL, Tong AKW, Vincent BC. The effects of fasting and transportation on beef cattle. 2. Body component changes, carcass composition and meat quality. Livest Prod Sci 1988;20:25.

97. Knowles TG, Brown SN, Warriss PD, et al. Effects on sheep of transport by road for up to 24 hours. Vet Rec 1995; 136:431-438.

98. Kannan G, Terrill TH, Kouakou B, Gazal OS, Gelaye EA, Samaké S. Transportation of goats: effects on physiological stress responses and live weight loss. J Anim Sci 2000;78: $1450-1457$.

99. Moran ET, Bilgili SF. Influence of broiler livehaul on carcass quality and further-processing yields. J Appl Poult Res 1995;4(1):13-22.

100. Deutsch $\mathrm{CH}$. Trying to connect the dinner plate to climate change. New York Times 29 August 2007.

101. McMichael AJ, Powles JW, Butler CD, Uauy R. Food, livestock production, energy, climate change, and health. Lancet 2007 Sep 12; [Epub ahead of print].

102. Crew J. Cargill commits to cut greenhouse emissions. Meat Poultry.com March 12, 2007.

103. Smithfield Foods joins the Chicago Climate Exchange. PRNewswire-FirstCall via COMTEX, February 25, 2007.

104. Rollin BE. Annual meeting keynote address: Animal agriculture and emerging social ethics for animals. J Anim Sci 2004 Mar;82(3):955-964.

105. Moore DW. Public lukewarm on animal rights: supports strict laws governing treatment of farm animals, but opposes bans on product testing and medical research. Gallup Poll News Service, May 21, 2003.

106. Zogby International. Nationwide views on the treatment of farm animals. October 22, 2003.

107. U.S. Highway Accidents Involving Farm Animals. Watkins Glen, NY: Farm Sanctuary; 2006.

108. COK investigation exposes farmed animal suffering during interstate transport. July 2005. http://www.cok.net/feat/ usti.php. Accessed November 2, 2007.

109. Council Regulation (EC) No 1/2005 of 22 December 2004. http://europa.eu.int/eur-lex/lex/LexUriServ/site/en/oj/ 2005/1_003/1_00320050105en00010044.pdf. Accessed July 2007.

110. Gavinelli A, Simonin D. The transport of animals in the European Union: the legislation, its enforcement and future evolutions. Vet Res Commun 2003;27 Suppl 1: $529-534$

111. EU tightens animal transport rule. $B B C$ News, January 5 , 2007. http://news.bbc.co.uk/2/hi/europe/6232563.stm. Accessed July 2007.

112. Canadian Food Inspection Agency. Advance Notice of Possible Changes to Animal Transportation Regulations in Canada. October 30, 2006. http://www.inspection.gc.ca/ english/anima/heasan/transport/notavie.shtml. Accessed November 2, 2007.

113. Compassion in World Farming. Europe's Long Distance Transport of Live Animals. 2003. http://www.ciwf.org.uk/ publications/reports/europes_long_distance_transport_of_ live_animals_2003.pdf. Accessed July 2007.

114. Food and Agriculture Organization. Europe still threatened by animal epidemics: better disease control required. February 17, 2005. http://www.fao.org/WAICENT/OIS/PRESS NE/PRESSENG/1998/pren9805.htm. Accessed July 2007. 
115. Scientific Committee on Animal Health and Animal Welfare. The welfare of animals during transport 3. Report for the European Commission. Adopted by the European Commission March 30, 2004.

116. Office International des Epizooties. The OIE's initiatives in animal welfare. February 27, 2007. http://www.oie.int/eng/ bien_etre/en_introduction.htm. Accessed May 2007.

117. Office International des Epizooties. Guidelines for the transport of animals by land. Terrestrial Animal Health Code. Appendix 3.7.3. 2006. http://www.oie.int/eng/ normes/mcode/en_chapitre_3.7.3.htm. Accessed May 2007.

118. European Food Safety Authority. Opinion of the Scientific Panel on Animal Health and Welfare on the request from the Commission related to the welfare of animals during transport. EFSA J 2004;44:1-46. http://www.efsa.europa. eu/EFSA/efsa_locale1178620753812_1178620775565. htm. Accessed November 2007.

119. King GA, Logan SH. Optimum location, number and size of processing plants with raw product and final product shipments. J Farm Econ 1964;46(1):94-108.

120. Food and Agriculture Organization. Proceedings of the Regional Workshop on Area-Wide Integration of Crop-Livestock Activities; June 18-20, 1998; Bangkok, Thailand. http://www.fao.org/WAIRDOCS/LEAD/X6105E/x6105e 00.htm. Accessed July 2007.

121. Tarrant PV, Grandin T. Cattle transport. In: Grandin T, ed. Livestock Handling and Transport. Wallingford, Oxon, UK: CAB International; 2000:151-173.

122. Hartung J. The new EU animal transport regulation: improved welfare and health or increased administration? Deutsche tierärztliche Wochenschrift 2006;113(3):113-116.

123. Hartung J. Effects of transport on health of farm animals. Vet Res Commun 2003;27(Suppl 1):525-527.

124. Guise J. Humane animal management: the benefits of improved systems for pig production, transport and slaughter. In: Carruthers SP, ed. Farm Animals: It Pays to Be Humane. CAS Paper 22. Reading, UK: Centre for Agricultural Strategy; 1991:50-58.

125. Grandin T. Introduction management and economic factors of handling and transport. In: Grandin T, ed. Livestock Handling and Transport. Wallingford, Oxon, UK: CAB International; 2000:1-14.
126. National Research Council. Guidelines for the Humane Transportation of Research Animals. Washington, DC: National Academies Press; 2006.

127. King NB, Edgington BH, Ferguson LC, Thomas DL Jr, Pounden WD, Klosterman E. Preliminary results in the control and treatment of shipping fever complex in beef cattle. J Am Vet Med Assoc 1955;27:320-323.

128. Lofgreen GP. Mass medication in reducing shipping feverbovine respiratory disease complex in highly stressed calves. J Anim Sci 1983;56:529-536.

129. Tollefson L, Fedorka-Crayn PJ, Angulo FJ. Public health aspects of antibiotic resistance monitoring in the USA. Acta Vet Scand Suppl 1999;92:67-75.

130. International Meat Animal Welfare Research Conference. February 17, 2004; Kansas City, Missouri.

131. 32nd International Animal Air Transportation Association Conference. April 23-26, 2006; Amsterdam, The Netherlands.

132. OIE Global Conference on Animal Welfare. February 23-25, 2004; Paris, France.

133. Animal Welfare in Europe: achievements and future prospects. November 23-24, 2006; Strasbourg, France.

134. Bench C, Schaefer A, Rushen J, et al. The welfare implications of the transport of pigs: the scientific background of current international transport duration standards. $A d v$ Pork Prod 2007;18:A-26.

135. European Commission. Questions and answers on footand-mouth disease (FMD). 12 December 2001. http:// ec.europa.eu/dgs/health_consumer/library/press/press215_en. pdf. Accessed July 2007.

Manuscript received June 1, 2007;

accepted for publication October 11, 2007.

Address reprint requests to: Michael Greger, MD

Director, Public Health and Animal Agriculture The Humane Society of the United States 2100 L St., NW

Washington, DC 20037

E-mail:mhg1@cornell.edu 